\title{
TEACHING METHODS OF PRACTICE STYLE AND COMMAND STYLE IN IMPROVING THE SKILL OF BUTTERFLY STROKE
}

\author{
Argantos $^{1}$, James A.P. Tangkudung ${ }^{2}$ \\ ${ }^{1}$ A lecturer of Faculty of Sports Science Universitas Negeri Padang, Indonesia \\ ${ }^{2}$ Universitas Negeri Jakarta, Indonesia \\ 1argantos_pyk@yahoo.co.id
}

\begin{abstract}
The objective of this research is to find out different impacts of the teaching methods; practice style and command style. This research is conducted in the Faculty of Sports Science, State University of Padang during the academic year of 2010/2011. The applied research method is an experimental method. The sample consists of 40 (college) students who are divided into 4 groups of 10 persons. The data analysis technique is performed by a two-ways variance analysis followed by the tukey test at the significance level $=0,05$. The results of this research are: 1) in all aspects, the skill of butterfly stroke by the teaching method of command style is better than the practice style, 2) for the students with high motor skills, the skill of butterfly stroke by the teaching method of practice style is better than the command style, and 3) for the students with low motor skills, the skill of butterfly stroke by the teaching method of command style is better than the practice style.
\end{abstract}

Keywords: teaching methods of practice style and command style; motoric abilities; the skill of butterfly stroke.

A butterfly stroke is one of the swimming strokes with the breast position on the water surface. Both arms are simultaneously pressed down and moved outwards before being swung forward (Fina Handbook, 2002-1005: 126). Both legs kick down and up simultaneously like the fin movement of fish or dolphins. The breathing is processed when the air is blown vigorously through the mouth and nose before the head emerges toward the air and the air is breathed through the mouth when the head is on the water (http://id.wikipedia.org/wiki/gayakupu-kupu).

Compared to the other swimming strokes, the butterfly stroke requires great strength of a swimmer. The speed of this stroke is gained from the simultaneous swing of both arms. This butterfly stroke is the newest stroke in swimming. Different from the freestyle stroke, breaststroke, and backstroke that are normally deemed easy to do, the beginners need longer time to learn the coordination between the arms and legs movement in the butterfly stroke. Most beginners think this stroke as the most difficult one to learn.

Being able to swim in the butterfly stroke is pride for every swimmer due to its difficult movement characters (http://abdurrosyid.wordpress.com/renanggaya kupukupu). On the other hand, the ability to do this stroke will make every swimmer proud. We must love seeing this stroke due to its beauty; from the upper side, the swimmers seen like flying with their arms on the water and from the lower side we may see them to fly and glide like an eagle or parachutist.

No matter how difficult the butterfly stroke is, if it is taught with the right approach of teaching method, the technique will be well performed. It requires more 
effective learning process and steps. The activity of body movement in this stroke is started with the first arms movement after the start, and the body reversal remains to be face-down and both shoulders should be in line with the normal water surface (Cecil M. Colwin, 2002: 57). The movement indicators consist of: 1) body position, 2) leg movements, 3) arm movements, 4) breathing and 5) motor coordination. After that, both arms must be simultaneously pushed toward the surface of the water and be pulled backward constantly during the activity.

Based on the above facts, the researcher is interested in improving the quality of learning process as one of the corrective efforts to improve the butterfly stroke skill. In order to improve the learning process and to develop the quality of learning process and result of the swimming course, an appropriate teaching method and style is required according to the movement characteristics of the swimming course. The appropriate swimming learning method will help the students to understand the techniques of swimming movement they learn. An interesting method in teaching swimming has not been realized until now. Most lecturers apply the conventional learning method in teaching swimming i.e. explaining the material through the exercise tasks which are held directly by them; all decisions during the material explanation are made by the lecturers and students are waiting for their lecturer's instruction. This teaching method is called as the command style. A teaching method during the lesson (Rusli Lutan, 1999 : 29) is an approach during the lesson aimed to give clear directions and steps which enable in developing the attitude and behavior changes, enhancing the absorption and retention, strengthening the intention, the possibility of a complex interaction between the components in that learning process. Besides, this teaching method is well-selected so that the students may get interested more to learn it. The experts often suggest that it is better to use a complete method and media in learning process so that it can increase their motivation. In order to achieve those things, the researcher conducts this research in two approaches: teaching method of practice style and command style during the class or learning of butterfly stroke (Musko Mosston and Sara Asworth, 2008: 14-17) as a good alternative to improve the butterfly stroke skill.

The swimming skill needs the potential motor skills in which all basic skills should be well-mastered because if the basic skills are inadequate, there will be some difficulties during the swimming e.g. easy to get tired and not be able to swim for a long distance. The movements in swimming include large muscles and joints involving the level of motor skills as it is known that every person has different motor skills.

According to Rusli Lutan (1988:96), a motor skill is an individual capacity related to the implementation and demonstration that relatively attached. The ability to master a new skill quickly or slowly is related to his/her motor skills. The success in learning a sport skill indicates that the person has good motor skills. One of ways to define that kind of success is to utilize the potential that could support the individual success in learning the sport skill called as the motor skills (Rusli Lutan, 1988: 96). In other words, the success in learning the sport skill could be by utilizing all potential and other supporting aspects. There are many factors that may influence and cause the students' low skill of swimming including the butterfly stroke skill. Those factors consist of internal and external factors from the students who follow the learning process. The internal factor is the potential of each person that may affect the butterfly stroke skill e.g. the level of motor skills that may be classified 
into two groups i.e. a group of students with the high motor skills and a group of students with low motor skills. The external factor is the treatment used in this research i.e. the teaching method in learning (Muska Mosston and Sara Asworth, 2008: 14 -17), such as the teaching method with the practice style and the command style functioning to give a clear description of factors that influence the quality of the students' learning process and result in the butterfly stroke skill.

Hence, the teaching methods as the independent variables (variables) in this research are as follows: 1 . The teaching method of the practice style, and 2. The teaching method of the command style. The attribute variable is the students' motor skills consisting of: 1 . High motor skills, and 2. Low motor skills.

The dependent variables in this research are the butterfly stroke skill and the formulations of the problems which become the starting point in this research are as follows: 1) In general, are there any differences of the butterfly stroke skill between the students' who are trained by the teaching method the practice style and the command style? 2) Are there any differences of the butterfly stroke skill between the students with high motor skill who are trained by the teaching method the practice style and the command style? 3) Are there any differences of the butterfly stroke skill between the students with low motor skill who are trained by the teaching method the practice style and the command style?

\section{METHOD}

The research methodology used in this research is the experimental field research. The experimental field research may be defined as a research methodology used to find out the impacts of certain treatments against the other under controlled condition. Therefore, the scope and steps of the experimental field research are a way to find out the causal factors and to control the events within the interaction of variables and also to give its estimated result in certain level.

This research involves one dependent variable i.e. the students' skill of butterfly stroke; the independent variables i.e. 1) The teaching methodology of the practice style, 2) The teaching methodology of the command style ; and also the attribute variables i.e. the motor skills consisting of a) high motor skills and b) low motor skills.

The design used in this research is the factorial design $2 \times 2$ as shown in the table below:

Table 1. Factorial Design 2 X 2

\begin{tabular}{ccc}
$\begin{array}{c}\text { Teaching } \\
\text { Methodology } \\
\text { Motor Skills (B) }\end{array}$ & $\begin{array}{c}\text { Teaching Methodology The } \\
\text { Practice Style (A1) }\end{array}$ & $\begin{array}{c}\text { Teaching Methodology the } \\
\text { Command Style (A2) }\end{array}$ \\
\hline Low Motor Skills & A1B1 & A2B2 \\
\hline Total & (A1) & (A2)
\end{tabular}

Notes:

A1B1 = A group of students with high motor skills that taught by the practice style.

$\mathrm{A} 2 \mathrm{~B} 1=\mathrm{A}$ group of students with high motor skills that taught by the command style. 
A1B2 = A group of students with low motor skills that taught by the practice style.

A2B2 = A group of students with low motor skills that taught by the command style.

A1 = A teaching methodology by the practice style.

A2 = A teaching methodology with the command style.

B1 = The high motor skills

B2 = The low motor skills

The population in this research is the students of the Faculty of Sports Science of State University of Padang (UNP), with the accessible population are the male students majoring in coaching (particularly male) who have passed the basic swimming subject and registered for the semester of July - December 2011.

The sampling technique is performed through the tests of motor skills of 74 students in the population; the group of students with high motor skills and the group of students with low motor skills. Each group is taken based on the percentage technique by Frank M. Verduci (1980: 176), they are 27\% of students with high motor skills and $27 \%$ of students with low motor skills. Align with the above statement and confirmed by Nurhasan (2001: 129) that if the participants are in large amount, then the group division of upper group and lower group is taken from the $27 \%$ of the students having high score as the upper group and the other $27 \%$ from the students having low score as the lower group. The calculation result from 27: $100 \times 74=19.98$ rounded up 20 persons. Thus, the samples are 20 students with high motor skills and 20 students with low motor skills.

Table 2. The distribution of research samples

\begin{tabular}{lll}
$\begin{array}{r}\text { Teaching } \\
\text { Methodology } \\
\text { (A) }\end{array}$ & $\begin{array}{c}\text { Teaching Methodology } \\
\text { The Practice Style (A1) }\end{array}$ & $\begin{array}{c}\text { Teaching Methodology } \\
\text { The Command Style (A2) }\end{array}$ \\
\hline High Motor Skills (B1) & 10 & 10 \\
\hline Low Motor Skills (B2) & 10 & 20 \\
\hline Total & 20 & 10 \\
\hline
\end{tabular}

\section{RESULTS}

After the testing of normality and homogeneity of the proven data of research result, it is clear that the requirements for variance analysis have been fulfilled. Therefore, the two-ways variance analysis (anava) may be used for the hypothesis testing.

Table 3. Result Summary of Calculation (anava) 2 × 2

\begin{tabular}{|c|c|c|c|c|c|c|c|}
\hline \multirow{2}{*}{$\begin{array}{l}\text { Variance } \\
\text { Source }\end{array}$} & \multirow{2}{*}{$\mathrm{dk}$} & \multirow{2}{*}{ JK } & \multirow{2}{*}{ RJK } & \multirow{2}{*}{\multicolumn{2}{|c|}{ F calculate }} & \multicolumn{2}{|c|}{ F table } \\
\hline & & & & & & $\alpha=0.05$ & $\alpha=0.01$ \\
\hline $\begin{array}{l}\text { Between the } \\
\text { groups }\end{array}$ & 3 & $1,671.616$ & 557.205 & 10.772 & $\#$ & 2.839 & 4.313 \\
\hline In the group & 36 & $1,862.256$ & 51.729 & & & & \\
\hline Column (A) & 1 & 10.300 & 10.300 & 0.199 & $* *$ & & \\
\hline
\end{tabular}




\begin{tabular}{lccccccc} 
Row (B) & 1 & 975.851 & 975.851 & 18.865 & $\#$ & 4.091 & 7.333 \\
Interraction & 1 & 685.464 & 685.464 & 13.251 & $* *$ & & \\
\hline Total & 39 & $3,533.87$ & & & & & \\
\hline
\end{tabular}

\begin{tabular}{ll}
\hline Notes: & \\
$\#$ & $=$ Significant rate $\alpha=0,05$ \\
Dk & $=$ Independent degree \\
JK & $=$ Sum of squares \\
RJK & $=$ Average Sum of Squares \\
Fhitung & $=$ Price F observasi \\
Ftabel & $=$ Price F tabel
\end{tabular}

Based on that variance analysis (anava), it is found that the $\mathrm{F}_{\text {calculate }}$ between the columns $(\mathrm{FA})=0.199$ is smaller than $\mathrm{F}_{\text {table, }}$ which is $4.091(\mathrm{Fo}=0.199<\mathrm{Ft}=4.091)$ so that Ho could not be rejected or received. Based on this calculation, it can be concluded that generally there is no significant impact between the approach of teaching the butterfly stroke by the practice style or command style.

Therefore, it could be said that the average swimming skill of butterfly stroke of students taught by the command style have an average score, $\mathrm{x}=50.53$ and deviation, $\mathrm{s}=8.38$ which is better than the butterfly stroke skill of students taught by the practice style with an average score, $x=49.51$ and deviation, $s=10.74$. This shows the first research hypothesis stating that the butterfly stroke skill of students taught by the practice style is better than the students taught by the command style in all aspects.

The difference of the butterfly stroke skill between the teaching method of the practice style and command style is for the group of high motor skills.

According to the result stated in the summary of variance analysis (anava) calculation, the next phase calculation with the tukey test is to compare the group level of high motor skills and both experimental experiences related to the different impact on the butterfly stroke skill for the group of students with hight motor skills taught by the teaching method of the practice style and the teaching method of the command style.

Table 4. The summary result of Tukey test calculation.

\begin{tabular}{ccccc}
\hline No & Compared Groups & Q kartu & Q tabel 0.05 & Remark \\
\hline 1 & P1 with P2 & 3.37 & 4.33 & Not - Significant \\
\hline 2 & P4 dengan P3 & 0.741 & 4.33 & Not Significant \\
\hline
\end{tabular}

Based on the table above, it shows that the price $\mathrm{Q}_{\text {calculate }}=3.37$ is smaller than the $\mathrm{Q}$ table $=4.33$ or table $\mathrm{Q}_{\text {calculate }}<\mathrm{Q}$ in the significant rate 0.05 . Therefore, the zero hypothesis is received and the alternative hypothesis is rejected. This means that the butterfly stroke skill of students with high motor skills taught by the practice style has an average score, $\mathrm{x}=58.59$ and deviation, $\mathrm{s}=5$ which is better than the students taught by the command style approach with an average score, $\mathrm{x}=51.33$ and deviation, $\mathrm{s}=10.76$. Though the tukey test shows the insignificant differences, this leads to the third hypothesis stating that for students with high motor skills, their 
swimming skills of butterfly stroke of students taught by the practice style is better than the students taught by the command style.

In line with the result stated in the next phase of variance analysis calculation summary of tukey test in comparing the group level of low motor skills and both experimental methods related to the different impact of the butterfly stroke skill for the group with low motor skills taught by the practice style and the commando style, it shows that the price $\mathrm{Q}_{\text {calculate }}=.0 .741$ is smaller than the $\mathrm{Q}$ table $=4.33$ or table $\mathrm{Q}_{\text {calculate }}<\mathrm{Q}$ in the significance rate 0.05 . Therefore, while the zero hypothesis stating that there is no difference of the butterfly stroke skill between the groups with low motor taught by the commando style and the practice style is rejected, the alternative hypothesis is received. This means that the butterfly stroke skill for students with low motor skills taught by the command style is better than the practice style, is proven. According to the result stated in the summary of variance analysis calculation and the further calculation by the tukey test, the average for the teaching method approach of the command style is $x=49.73$ and deviation, $s=5.56$ and the average for the teaching method approach of the practice style is $x=40.33$ and deviation, $s=4.97$. This means that the fourth hypotheses stating that for students with low motor skills, the butterfly stroke skill for students taught by the command style is better than the practice style, is proven.

\section{DISCUSSION}

Generally, the teaching method approach of command style is better than the practice style for the butterfly stroke skill. This means that the teaching method of command style and practice style could improve the skill of butterfly stroke. However, the implementation is different. The difference is because the teaching method of practice style in swimming lesson is a systematic way for the efficiency of learning or training and it also provides personal/individual learning to the students during the lesson. To achieve the expected goal, the lecturer will then give feedback individually or personally with the identified indicators according to the anatomy styles consisting of: 1) pre meeting; decided by the lecturer, 2) the meeting: decided by the student, 3 ) after meeting: decided by the lecturer.

The strength is the lecturer may fairly give authorization to the students in many things during the lesson. The lecturer defines the concept and scope of learning until the end of learning process before the meeting starts (pre meeting). After the learning process starts, the student could choose some alternatives to be used to facilitate the understanding and lesson-mastery according to the requirements to master the butterfly stroke skill. The student is authorized to make any decision that the result be more open. The lecturer may take the decision once they are in the after meeting. This thing is considered as the strength for the teaching method of practice style. On the other hand, the student's authority is considered as the weakness caused by more open situation.

The command style is a systematic way for the efficiency of learning or training for it provides direct responses for the stimulus. In order to achieve the expected goal, the lecturer gives examples and the student imitates with the indicators identified according to the anatomy styles consisting of: 1) pre meeting; decided by the lecturer, 2) the meeting: decided by the lecturer, 3) after meeting: decided by the 
lecturer. During the lesson of butterfly stroke skill, the lecturer performs the instructional task according to the programs designed based on the swimming synopsis and syllabus.

The above analysis result is determined by the result of variance analysis (anava) calculation about the efficiency difference between both lesson approaches in general, which is Fobservation between the columns $(\mathrm{FA})=0.1999$ is smaller than the Ftabel $=4 / 091($ Fo $0.199<\mathrm{Ft}=4.091)$. By considering the average skill of the butterfly stroke taught by the practice style: the obtained average score, $x=49.52$ and deviation, $\mathrm{s}=10.74$ compared to the average skill of butterfly stroke taught by the command style: the obtained average score, $x=50.53$ and deviation, $s=8.38$, it can be concluded that in teaching the butterfly stroke skill, the method of the command style is better than the practice style.

Therefore, based on the research results, the recommendation is that even it may not impact the skill of butterfly stroke significantly; the practice style could be applied during the learning process. This is caused by some factors, which are: 1) Internal factor, which is the professional capability of a teacher or lecturer in holding the learning process. Professional profile and competency are influential indicators impacting the learning process and result. On the side of students as the study subject, this also impacts the process and the achieved result during the lesson, particularly the students' preparation and motivation, 2) External factors that directly impact the learning process in this research are facilities and infrastructures supporting this research activity. This research location is outside the area of FIK UNP and this does not create conducive environment to learn.

Particularly for students with high motor skills taught by the practice style is better than the command style in learning the butterfly stroke skill. This means that both teaching methods (the practice style and command style) could improve the students' skill of butterfly stroke. However, each of them has differences during the implementation.

The result of the above variance analysis (anava) calculation is reinforced by the result of further testing on the group of high motor skills who learn by using the practice style (the practice style, $\mathrm{P} 1$ ) compared to the group of high motor skills who learn by using the command style (the command style, $\mathrm{P} 2$ ). The results are $\mathrm{Q}_{\text {calculation }}$ $3.37<\mathrm{Q}$ tabel 4.33. Hence, the students with high motor skills that taught by the practice style has obtained the average score, $x=58.59$ and deviation, $s=5.96$ is realistically true compared to the students with high motor skill that taught by the command style with the average score, $x=51.33$ and deviance, $s=10.76$.

Thus, based on the discussion of the research result, it is recommended that for students with high motor skills, the teaching method of practice style is better to be applied in improving the students' butterfly stroke skill.

Particularly for the students with low motor skill who learn the butterfly stroke, the teaching method of command style is better than the practice style. This means that both treatments may improve the learning result and the butterfly stroke skill for the students of FIK UNP. However, each of them has difference. The method teaching of the command style is one of methods in teaching that is used by teachers and lecturers during the sport lesson because this method may improve the quality of the learning process and result. The teaching method of the command style is very simple that it may use simple tools for students with low motor skills. 
The result of the above variance analysis (anava) calculation is reinforced by the result of further testing on the group of low motor skills who learn by using the command style (the command style, P4) compared to the group of low motor skills who learn by using the practice style (the practice style, $\mathrm{P} 3$ ). The results are $\mathrm{Q}_{\text {calculation }}$ $0.741<\mathrm{Q}$ table 4.33 .

Hence, the effectiveness of the command style with the low motor skill students has obtained the average score, $x=49.73$ and deviation, $s=5.56$ and realistically is true compared to the teaching method taught by the command style with the average score, $x=49.73$ and deviance, $s=5.56$, which is better compared to the practice style consisting the average score, $\mathrm{x}=40.43$ and deviance, $\mathrm{s}=4.97$.

Thus, based on the discussion of the research result, it is recommended that for students with low motor skills, the teaching method of command style is better to be applied in improving the skill of butterfly stroke.

\section{CONCLUSION}

Generally for the students' skill of the butterfly stroke, the teaching method of command style is better than the practice style. Students with high motor skills that taught by the practice style is better than taught by the command style and students with low motor skills taught by the command style is better than taught by the practice style.

\section{REFERENCES}

Colwin M, Cecil. (2002). Breakthrough Swimming. United States: Human Kinetics.

Fina Handbook, Contitutions and Rules, Swimming, Open Water Swimming, Diving, Water polo, Synhcronised Swimming and Doping Control, Fina office, 20052009.

Gagne, Robert M, Briggs Leslie. J \& Wager Walter W. (1992). Principles of Instructional Design. New York: Reinhart and Wiston, Inc.

Harsuki. (2012). Pengantar Manajemen Olahraga, Jakarta: PT Raja Grafindo Persada.

httpstaff.uny.ac.Idsitesdefaultfilesgaya\%20mengajar\%20Mosston.pdf

http://onopirododo.wordpress.com/akuatik/16-2-2012

http://puspita-sc.blogspot.com/2010/08/renang-gaya-kupu-kupu-butterflystroke.html

Lutan, Rusli. (1988). Belajar Keterampilan Motorik Pengantar dan Metode. Jakarta: Depdikbud. 
Maglischo, Ernest W. (2004). Swimming Event Faster. United States: Human Kinetics Champign.

Mosston, Muska and Sara Ashworth. (2008). Teaching Physical Education. First Online Edition.

Tangkudung, James. (2006). Ilmu Faal (Fisiologi), Jakarta: Penerbit Cerdas Jaya.

Verducci, Frank M. (1980). Measurement Concepts in Physical Education. San Francisco, California: The C.V. Mosby Company. 